\title{
DESIGUALDADES RACIAIS NO ESPAÇO URBANO
}

\section{Racial inequalities in the urban space}

Inaiá Maria Moreira de Carvalho

(UCSAL)

LATTES iD http://lattes.cnpq.br/6436834586482218

Informações do artigo

Recebido em 07/05/2020

Aceito em 13/05/2020

doi>: https://doi.org/10.25247/2447-861X.2020.n249.p137-166

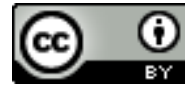

Esta obra está licenciada com uma Licença Creative Commons Atribuição 4.0 Internacional.

\section{Como ser citado (modelo ABNT)}

CARVALHO, Inaiá Maria Moreira de. Desigualdades raciais no espaço urbano. Cadernos do CEAS: Revista Crítica de Humanidades. Salvador, v. 45, n. 249, p. 137166, jan./abr. 2020. DOI: https://doi.org/10.25247/2447-

861X.2020.n249.p137-166

\begin{abstract}
Resumo
Este texto se propõe a discutir como os padrões e os impactos da segregação sócio espacial se articulam com as desigualdades raciais na sociedade brasileira, com base em dados dos Censos demográficos, das PNADS e de algumas pesquisas empíricas realizadas em Salvador, capital do Estado da Bahia, que constitui atualmente a quarta maior cidade do país e onde os negros representam a absoluta maioria da população. Para tanto, ele se reporta inicialmente à questão da segregação e do denominado "efeito território", abordando a literatura sobre esses fenômenos e sobre o seu desenvolvimento. Analisa, a seguir, como os padrões de segregação se articulam com as desigualdades raciais e como a concentração de moradores pobres e majoritariamente negros em áreas homogêneas, precárias e desassistidas agrava a sua despossessão e a sua vulnerabilidade, ressaltando que a apropriação diferenciada do território urbano também contribui para a persistência e para o agravamento das desigualdades raciais no Brasil.
\end{abstract}

Palavras-chave: Segregação sócio espacial. Desigualdades Raciais. Salvador. Brasil.

\section{Abstract}

This essay suggests a discussion on how the patterns and the impacts of the socio- spatial segregation articulate with the racial inequalities in the Brazilian society, based on the data from the Demographic Census, from the PNADS (National Research by Home Sample) and from some empirical researches done in Salvador, capital of the state of Bahia, actually the fourth largest city of the country and where the black people represents the absolute majority of the population. For that, this essay refers initially to the question of segregation and to the referred "territory effect", approaching the literature about these phenomena and their development. It analyses, next, how the patterns of segregation are articulated with racial inequalities and with the concentration of poor inhabitants, mainly black people, in zones precarious and most in needs, worsens their dispossession and their vulnerability, emphasizing that a differentiated appropriation of the urban territory contributes also to the persistence and to the aggravation of the racial inequalities in Brazil.

Keywords: Socio-spatial segregation. Racial Inequalities. Salvador. Brazil. 


\section{Introdução}

Tanto a necessidade de uma certa concentração espacial de infraestrutura e serviços como a trajetória e os padrões de desenvolvimento do Brasil e de outros países da América Latina levaram à constituição de complexos sistemas urbanos, onde alguns grandes centros assumiram uma configuração metropolitana. Concentrando a população, a produção e a riqueza, esses centros também são marcados, paralelamente, pelo seu caráter desigual, segregado e excludente, transformando-se, atualmente, no epicentro da crise social que afeta essas cidades e assumindo um significativo destaque na agenda dos estudos urbanos.

Integrando um conjunto de investigações desenvolvidas pela rede de pesquisadores do INCT/Observatório das Metrópoles sobre as condições e transformações contemporâneas dos referidos Centros, este artigo analisa em que medida os processos de segmentação, diferenciação e apropriação do território urbano interferem sobre os fenômenos em questão. Mais precisamente, ele se propõe a estudar como os padrões de segregação que prevalecem nas metrópoles brasileiras contribuem para reproduzir e acentuar as desigualdades sociais e raciais, afetando amplos segmentos da população em decorrência da localização da sua moradia no espaço urbano, com base no caso de Salvador, primeira capital do país e, atualmente, uma das suas maiores cidades, cuja população é majoritariamente negra.

Para atender a esses objetivos, será utilizada uma tipologia sócio espacial, elaborada através de tabulações especiais dos Censos de 2000 e de 2010, com a metodologia desenvolvida pelo INCT/Observatório das Metrópoles, assim como informações de outros órgãos oficiais e pesquisas desenvolvidas anteriormente pela autora e por outros investigadores sobre a metrópole baiana.

Além desta Introdução, o presente artigo abrange mais três secções; aquela que se segue aborda teoricamente os fenômenos da segregação e do "efeito território". A terceira discute as especificidades e os impactos desses fenômenos no que se refere à vulnerabilidade e às desigualdades na capital baiana. Na última secção são apresentadas algumas observações finais. 


\section{O fenômeno da segregação}

O fenômeno da segregação tem despertado a atenção dos cientistas sociais, urbanistas e pesquisadores desde a primeira metade do século vinte, com os estudos da Escola de Chicago que abordavam a segregação racial entre brancos e negros nos Estados Unidos, reportando-se, posteriormente, a outros grupos étnico-raciais. O crescimento e a concentração da pobreza nos guetos negros das grandes cidades americanas nas últimas décadas do século passado renovaram o interesse por essa discussão, e, na esteira do clássico estudo de Wilson (1987), multiplicaram-se trabalhos como os de Jargowsky, Small e Newman (2001) ou de Wacquant (2008). Análises sobre esse fenômeno também se desenvolveram na França e em outros países europeus, onde a diferenciação da cidade e a segregação residencial passaram a ser enfocadas a partir das distintas categorias socioeconômicas. Essa discussão também foi revigorada com a difusão do paradigma das cidades globais, que teriam entre suas características uma tendência à dualização social e urbana, com pesquisas sobre como as transformações econômicas e sociais do capitalismo contemporâneo estariam agravando sua intensidade e suas perversões (SASSEN, 1991; SHAPIRA, 2000; PRETEICELLE, 2003; SABATINI; CÁCERES; CERDA, 2004).

No Brasil e em outros países da América Latina, porém, a ocorrência desse fenômeno foi por muito tempo ignorada ou até questionada em decorrência da sua identificação com a problemática norte americana da tradução espacial da questão racial e do seu entendimento como uma separação forçada e legalmente estabelecida, como nos casos do gueto judeu, do gueto negro e do apartheid da África do Sul. Mais recentemente, porém, discussões mais refinadas sobre o significado, intensidade, procedimentos de medida e formas de ocorrência da segregação levaram a um reconhecimento do seu caráter histórico e plural, e de que a mesma se manifesta e pode ser estudada com base no grau de proximidade ou de concentração residencial de famílias pertencentes a um mesmo grupo (seja este definido em termos étnico raciais, socioeconômicos, culturais ou religiosos), com a concentração de alguns grupos em espaços específicos do território urbano e a constituição de grandes áreas relativamente homogêneas (VILLAÇA,1998; CLADEIRA, 2000).

Como uma expressão coletiva das desigualdades e da cultura material da cidade, aquelas onde residem os grupos de alta e média renda estão situadas geralmente na área central ou em uma direção específica do referido território, sendo bem providas de infraestrutura e de equipamentos de uso coletivo. Aí se concentram os mais importantes 
centros de comércio, de saúde e de educação, espaços de cultura e de lazer como parques, teatros e museus, monumentos e amenidades de várias ordens. Suas edificações são adequadas ou até luxuosas e tendem a refletir as mudanças e tendências estéticas e arquitetônicas contemporâneas. Já os espaços onde a população de baixa renda se aglomera normalmente carecem de infraestrutura e equipamentos básicos, estão localizados em áreas periféricas, distantes e, muitas vezes, inadequadas à ocupação, concentrando moradias precárias e autoconstruídas sem requisitos mínimos de habitalidade.

A partir dos anos 1990 e de trabalhos como os de Villaça (1998) e de Caldeira (2000) e dos numerosos estudos do Observatório das Metrópoles e do Centro de Estudos da Metrópole sobre a dinâmica e a estrutura social e urbana das grandes capitais do país, contudo, o referido debate avançou significativamente no Brasil. Com esse avanço, alguns estudos também têm abordado os denominados "efeito bairro", "efeito território", ou "efeitos do lugar", (BOURDIEU, 1997; SABATINI; WORMALD; RASSA, 2003; ANDRADE, SILVEIRA, 2013) compreendidos como o benefícios ou prejuízos que afetam determinados grupos sociais em função de sua localização no espaço urbano, com impactos no que se refere às condições e reprodução das desigualdades sociais, da vulnerabilidade e da pobreza. Uma produção nacional já expressiva se soma agora à vasta literatura internacional sobre essa questão (WILSON, 1987; BOURDIEU, 1997; JARGOWSKY, 1996; KAZTMAN; RETAMOSO, 2005), Preteceille, 2003; SERVAI, 2008; WACQUANT; VIGNOLLI (2008), MOLINATTI, 2013; SOLIS; PUGA, 2014).

Analisando os determinantes desses impactos, essa literatura assume diferentes orientações. Alguns autores privilegiam a interferência do entorno sobre os valores, comportamentos e a trama social, o processo de socialização coletiva, a influência dos pares e a maior exposição das novas gerações a problemas como o abandono escolar, a gravidez precoce e o envolvimento com drogas e com a criminalidade. Outros enfatizam o isolamento físico e social, o estreitamento das redes e do capital social, a distribuição dos serviços básicos e de outros recursos no espaço urbano (configurando uma "geografia de oportunidades" que penalizaria os moradores de determinadas áreas), assim como as transformações contemporâneas do capitalismo e suas consequências adversas sobre as condições e perspectivas de integração social. Em que pese essas diferenças, porém, há um consenso entre os diversos autores de que a aglomeração de grupos despossuídos em 
espaços relativamente homogêneos e segregados contribui para dificultar o seu acesso a diversas oportunidades e para agravar a sua despossessão.

Assim, no que tange à educação, pesquisas efetuadas em diversos países têm constatado a tendência das escolas públicas a se diferenciar conforme a composição social das áreas onde estão localizadas, com sérias desvantagens para aquelas que servem aos moradores das áreas periféricas e com alta concentração de pobres (AINSWORTH, 2002; TORRES, 2003; MARQUES; TORRES, 2005; ZENTEN, 2005; RIBEIRO, 2005; RIBEIRO et. al., 2010). Nessas escolas, crianças e jovens apresentam normalmente um pior desempenho e são mais afetadas por problemas como a repetência, o atraso e a evasão escolar. E, embora esse fenômeno esteja associado ao nível de educação, ao reduzido capital cultural e às condições sociais das famílias, a contribuição do sistema escolar não pode ser menosprezada.

Atendendo a uma clientela oriunda de famílias de baixa escolaridade e renda, os referidos estabelecimentos são comumente mais precários. Seus alunos pouco interagem com colegas de nível social mais elevado, deixando de ficar mais expostos aos efeitos positivos de contatos com aqueles que dispõem de um maior capital social e cultural. Regras de contratação e alocação de professores muitas vezes direcionam para os referidos estabelecimentos aqueles que obtiveram uma menor pontuação nos concursos ou os que ingressaram mais recentemente no magistério, enquanto os mais experientes ou com maior pontuação tendem a escolher as escolas mais centrais e "menos problemáticas" em termos de localização, acesso e perfil do alunato. Além disso, geralmente os professores são pouco preparados para lidar com crianças e jovens que fogem aos modelos idealizados, tendendo a desenvolver uma visão preconceituosa e negativa das características dos alunos e de suas possibilidades de aprendizagem (SILVA, 2016; SANTOS, 2018.). Nessas condições, a escola tem dificuldades de propiciar a esses alunos a aprendizagem e o avanço necessário para o alcance das condições educacionais exigidas para a conquista de melhores posições no mercado de trabalho.

Além disso, como para os trabalhadores de menor escolaridade e renda, informações e acesso às oportunidades de trabalho dependem principalmente de contatos e indicações pessoais, a homogeneidade da vizinhança e a estreiteza das redes se somam à visão negativa e ao estigma residencial que atinge as áreas em apreço, dificultando a integração produtiva dos seus moradores, principalmente no caso dos jovens, conforme diversos estudos têm evidenciado. Em pesquisas realizadas na capital e em outras cidades do Chile, por exemplo, 
Sabatini, Wormald e Rassa (2013), constataram como o isolamento espacial é adverso às possibilidades e condições de ocupação, contribuindo para a inatividade, para o trabalho precário, o desemprego e a persistência da pobreza. Notadamente no caso das mulheres, que têm maiores dificuldades de se deslocar para as áreas onde se concentram as atividades produtivas, em decorrência de questões como a necessidade de conciliar o trabalho com as responsabilidades domésticas ou os riscos de se expor a zonas e horários considerados como perigosos nesse deslocamento.

Gomes e Amitrano (2005) também comprovaram que, independentemente de outros atributos sociais (como sexo, cor, juventude ou escolaridade), a população residente nas áreas mais pobres também convivia com maiores taxas de desemprego. Entre outras razões, em decorrência da pequena oferta de oportunidades de trabalho e obtenção de renda nas referidas áreas, levando seus moradores a arcar com problemas e maiores custos de transporte e de tempo em deslocamentos para as áreas centrais e mais afluentes das cidades, onde se concentram as oportunidades de emprego e de obtenção de renda, assim como os diversos equipamentos e serviços.

Naqueles países de menor desenvolvimento e maior desigualdade social, a concentração do poder aquisitivo nas camadas de média e alta renda constitui o principal determinante dessa concentração em áreas centrais ou próximas àquelas onde residem essas camadas, enquanto nos espaços densamente povoados, onde se encontra a maioria da população, a renda dos seus moradores geralmente não é suficiente para estimular o surgimento de subcentros fortes e de maiores oportunidades ocupacionais. Muitos desses espaços sediam apenas algumas atividades mais diretamente associadas à vida e à reprodução cotidianas, como pequenas mercearias, obrigando os que ali residem a longos deslocamentos para procurar emprego ou para trabalhar. Isto se transforma em obstáculos à integração produtiva, notadamente no caso daqueles grupos com atributos menos valorizados no mercado de trabalho, como os jovens, os negros, as mulheres e aqueles dotados de uma menor escolaridade.

Ademais, em realidades como a do Brasil, alguns dos espaços em apreço (marcado pela informalidade e por uma menor presença do Estado e das instituições de segurança pública ou de uma ação repressiva e violenta das mesmas sobre a população) tem se tornado presas do tráfico de drogas e do crime organizado. Associado à superposição de carências, ao crescimento das desigualdades e à falta de perspectivas para a maioria dos jovens pobres, isto tem contribuído 
para a degradação dos padrões de sociabilidade e para um significativo crescimento da violência, agregando uma vulnerabilidade civil à vulnerabilidade socioeconômica e vitimando, principalmente, jovens negros do sexo masculino. Mas, ainda que esses jovens e o conjunto da população negra sejam predominantemente atingidos pelos problemas em discussão, em que pese o acúmulo de estudos, como a segregação é associada, fundamentalmente, às condições e desigualdades de caráter socioeconômico no país, poucos abordam suas relações com as desigualdades raciais aqui prevalecentes, podendo ser citados, entre os primeiros, os realizados por Telles (2003) e por Garcia (2009).

Reconhecendo que a dimensão racial não é auto evidente nem tem o mesmo caráter dos Estados Unidos ou da África do Sul, Telles critica a ideia de que a segregação residencial se deva apenas às diferenças de classe no Brasil, considerando que a raça não constitui uma categoria insignificante para a análise do fenômeno em questão. Procurando mensurá-la em algumas metrópoles brasileiras, o autor recorre a dois índices utilizados em larga escala nos Estados Unidos, o índice de dissimilaridade e o índice de exposição, constatando a existência de uma segregação moderada, se comparada aos padrões americanos. Na ausência de determinações oficiais à sua existência ou de indícios de que a segregação afete o mercado imobiliário, ela se deveria, além das diferenças de classe, ao racismo e à autossegregação. Famílias negras escolheriam suas moradias considerando, entre outros aspectos, a possibilidade de serem discriminadas, ou a preservação de vínculos culturais e religiosos com instituições como terreiros e candomblés. Para o autor, entre os grupos e áreas residenciais de alta renda, a segregação racial é mais acentuada, inclusive, pela ausência de classes médias e de uma elite negra que possam disputar esses espaços. Já entre os pobres, premidos pelas condições de sobrevivência a viver principalmente em moradias autoconstruídas nas periferias ou em outras áreas desfavoráveis, ela seria bem mais reduzida.

Já o estudo de Garcia tem como objetivo evidenciar em que medida a segregação tem um caráter não apenas social como racial, abordando como esse fenômeno se manifesta nas antigas capitais brasileiras, Salvador e Rio de Janeiro. Analisando a literatura sobre as relações raciais e a segregação residencial, a autora considera que a dimensão racial da sua ocorrência tem sido ignorada ou até negada pelos estudos urbanos, uma vez que a mesma nunca foi institucionalizada, embora a forma como o racismo se desenvolveu no Brasil tenha levado a uma estrutura sócio racial singular. Estudando a trajetória e a organização espacial das referidas capitais, com uma ampla utilização dos microdados do Censo de 2000, sua 
pesquisa destaca a existência de uma expressiva correlação entre a estratificação racial e a estratificação espacial. Tanto em Salvador como no Rio de Janeiro, os estratos superiores e brancos se encontram recorrentemente sobre representados em espaços privilegiados em termos econômicos, sociais, políticos e culturais, enquanto os negros se aglomeram em territórios precários e desprovidos dessas condições. Ademais, as hierarquias, desigualdades e localização no espaço urbano interferem decisivamente sobre as condições de vida e de bem-estar dos diferentes segmentos sócio raciais, em detrimento da população negra, mesmo naqueles centros em que ela é amplamente majoritária, como ocorre em Salvador.

Com uma orientação similar a desses estudos, o presente texto discute como os padrões de segregação residencial se articulam mais recentemente com as desigualdades raciais na capital baiana. Partindo de um artigo publicado anteriormente (CARVALHO; BARRETO, 2007) e abordando a influência do "efeito território" sobre as condições de vida do contingente negro, com base em novas tabulações especiais de dados do IBGE e das PNADS Contínuas efetuadas pela autora, ele também agrega constatações de pesquisas efetuadas mais recentemente por outros investigadores na referida cidade. A estrutura do artigo abrange a presente Introdução, uma segunda parte sobre os padrões socioeconômicos e raciais de segregação que prevalecem em Salvador e uma terceira sobre os impactos desses padrões, à qual se seguem algumas observações finais.

\section{Padrões de segregação e raça em Salvador}

Salvador foi a primeira capital e constitui, atualmente, a quarta maior metrópole brasileira, com uma população de 2.873.329 habitantes em 2018. Destacando-se pela beleza natural, por sua rica cultura e patrimônio histórico, a cidade teve os seus padrões atuais de apropriação do espaço urbano e de segregação definidos e consolidados a partir de 1960. Foi nesse período, marcado por uma extraordinária expansão econômica e populacional, pela modernização e metropolização da velha cidade, que seu desenvolvimento se orientou em torno de três grandes vetores: a Orla Marítima Norte, o denominado "Miolo" e o Subúrbio Ferroviário, no litoral da Baía de Todos os Santos, que se somaram à antiga área central, hoje relativamente estagnada, conforme apresentado pela Figura 1. 
Figura 1 - Vetores de Expansão de Salvador, anos 1970

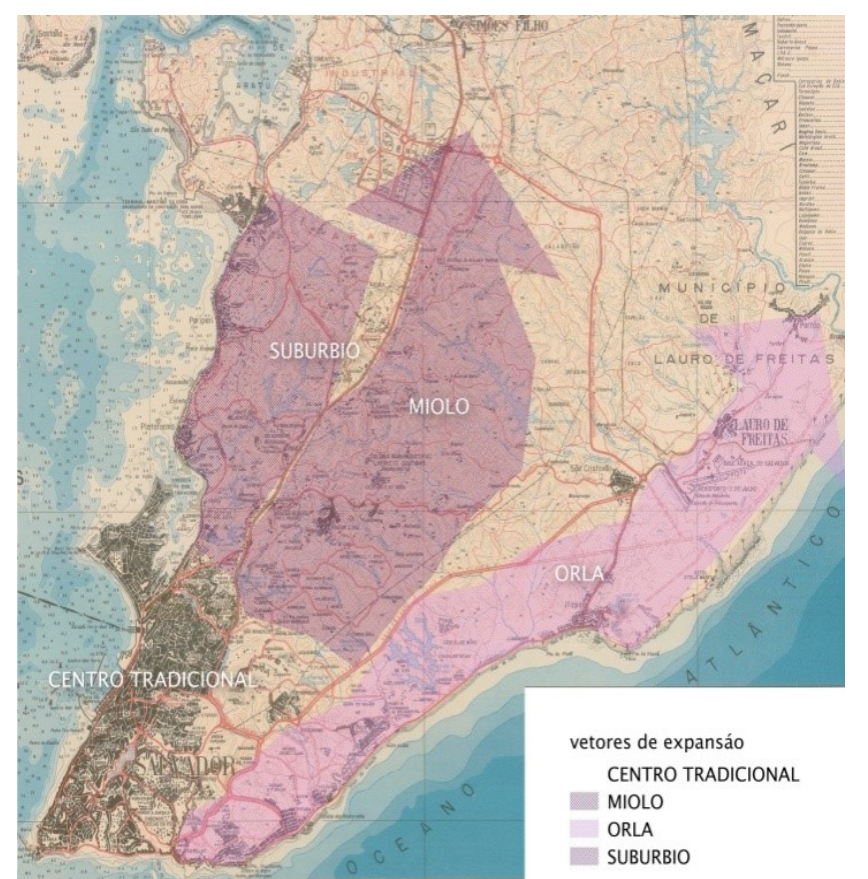

Fonte: CARVALHO, Pereira (2008). Elaboração dos autores

O primeiro constitui a área "nobre" da cidade, onde se concentram a riqueza, os investimentos públicos, os equipamentos e serviços urbanos, os espaços de lazer e os pontos de atração turística, assim como as oportunidades de trabalho e de obtenção de renda, ainda que essas últimas permaneçam relevantes no centro tradicional. O segundo, que tem essa denominação por estar localizado no centro geográfico do município, começou a ser ocupado com a implantação de conjuntos residenciais para a "classe média baixa", na fase áurea do Sistema Financeiro de Habitação, tendo a sua expansão continuada por loteamentos populares e sucessivas ocupações irregulares, com uma disponibilidade de equipamentos e serviços bastante restrita. Finalmente, o Subúrbio Ferroviário, que começou a ser habitado com a implantação de uma linha férrea, em 1860, tornou-se, a partir de 1940, a localização de vários loteamentos populares e ocupações irregulares. Para lá também foram transferidos moradores de assentamentos erradicados pela Prefeitura na "área nobre" da cidade, de forma que o Subúrbio se transformou em uma das áreas mais carentes da capital baiana, marcado pela precariedade habitacional, pelas deficiências de infraestrutura e serviços básicos, pela pobreza dos seus moradores e por altos índices de violência.

A apropriação diferenciada desses espaços e os padrões de segregação de Salvador foram analisados por Carvalho e Pereira $(2008,2014)$ com a metodologia do Observatório 
das Metrópoles, que envolve a utilização dos micro dados censitários para identificar e classificar a população economicamente ativa, agregá-la em categorias sócio ocupacionais mais abrangentes e analisar a sua distribuição no espaço urbano, utilizando como recorte territorial áreas definidas por uma agregação de setores censitários utilizadas em 2000 e 2010 pelo IBGE. Levando em conta como as diversas categorias estão representadas no território da cidade, foi elaborada uma tipologia que as classificou como superior, média superior, média, popular, e popular inferior, de acordo com a composição dos seus moradores. ${ }^{1}$ Com base nessa classificação ficou patente a ocupação da Orla Atlântica predominantemente por grandes empregadores, dirigentes e trabalhadores "intelectuais", ressalvando-se alguns enclaves de cunho popular como o Nordeste de Amaralina, a Boca do Rio e o Bairro da Paz. Os setores médios também ocupavam essas áreas, assim como o centro tradicional e as mais antigas da cidade. Já as áreas populares abrigavam a população que não tinha maiores possibilidades de escolha residencial, alojando-se, principalmente, em parcelamentos clandestinos e moradias precariamente construídas no Miolo e (ou) no Subúrbio. Os trabalhadores de subsistência tinham forte presença nessas áreas e em alguns pequenos interstícios da Orla Atlântica (Figura 2). E como a apropriação do espaço urbano está estreitamente articulada com a posição na estrutura social e com as desigualdades, essa divisão tem uma significativa conotação racial, com os referidos espaços sendo marcados igualmente por suas diferentes "cores".

\footnotetext{
${ }^{1}$ Nas áreas consideradas como superior predominavam os grandes empresários, o dirigentes do setor público e do setor privado, ao lado do grupo denominado como "intelectuais" (profissionais de nível superior, autônomos ou empregados); na média superior, o predomínio era dos intelectuais; na média os profissionais de nível superior se misturavam com pequenos empregadores e trabalhadores em ocupações técnicas, de escritório, ocupações médias de educação, saúde e similares; nas áreas de tipo popular se concentravam trabalhadores manuais da indústria e do comércio, assim como prestadores de serviços com alguma qualificação; nas classificadas como popular inferior, havia uma conjugação de prestadores de serviços não qualificados, trabalhadores domésticos, ambulantes e biscateiros.
} 
Figura 2 - Tipologia Sócio Espacial. Salvador, 2010

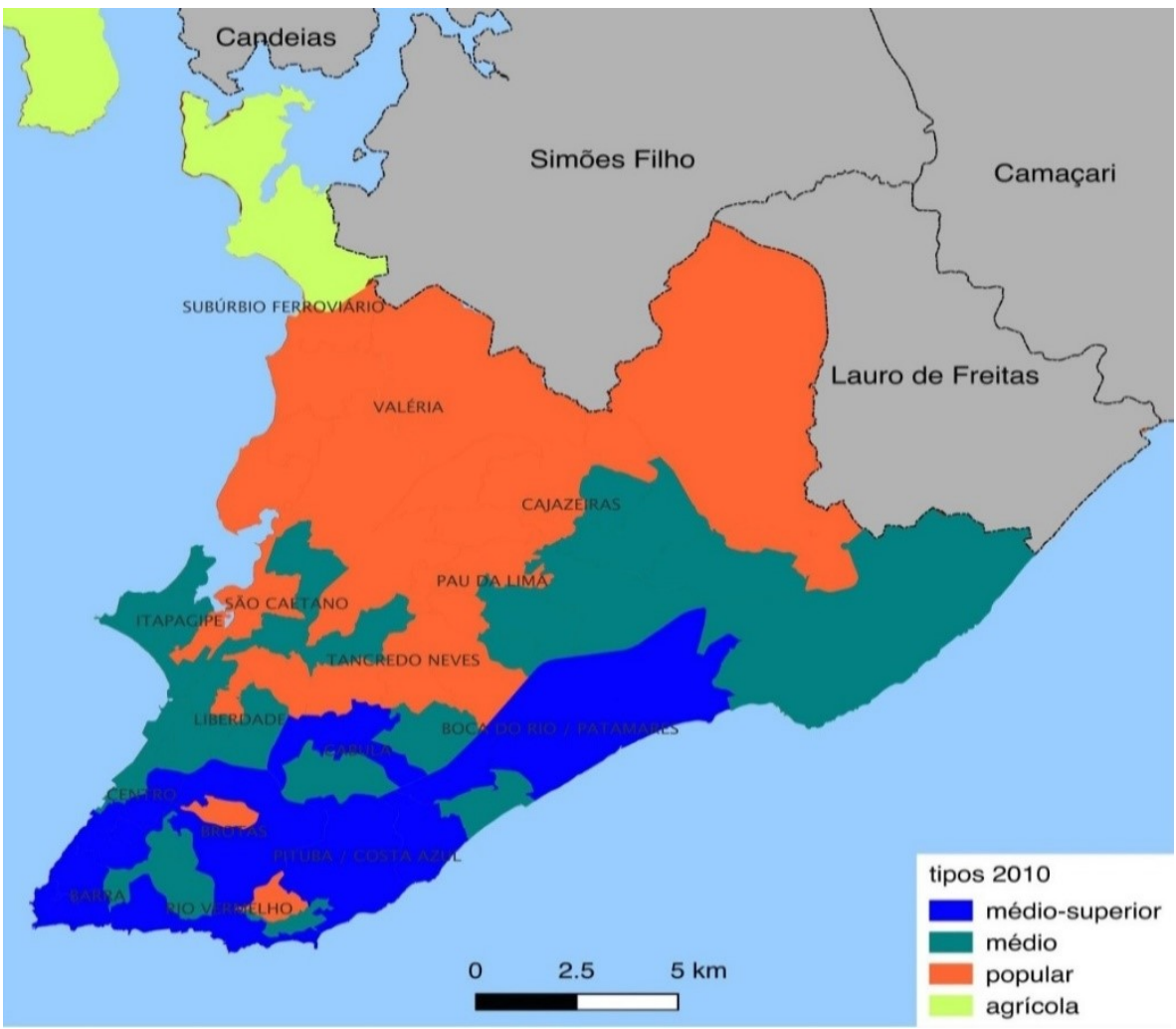

Fonte: IBGE, dados do Censo Demográfico de 2010. Conforme Carvalho e Pereira (2014).

Como se sabe, entre as características da capital baiana estão o seu restrito desenvolvimento econômico e a dimensão dos seus problemas sociais. Baixos níveis educacionais, carência habitacional, precariedade ocupacional, desemprego e pobreza atingemuma grande parcela dos seus moradores ${ }^{2}$, penalizando especialmente os negros 3 , o que pode ser observado por diversos indicadores, como os apresentados a seguir (Tabela 1).

\footnotetext{
2 No primeiro trimestre de 2018 , por exemplo, 34,2\% das pessoas de 14 anos e mais trabalhavam na informalidade e a taxa de desocupação chegava a 19,2\% em Salvador, conforme a Pesquisa Nacional por Amostra de Domicílios Contínua trimestral.

3 Como foi visto anteriormente, os negros representam a grande maioria da população da capital baiana. No Censo de $2010,17,9 \%$ dos seus moradores se autodeclararam brancos, $26,8 \%$ pretos e $53,4 \%$ pardos. Já na Pesquisa Nacional por Amostra de Domicílios Contínua do primeiro trimestre de 2018 esses números foram de, respectivamente, $16,8 \%, 33,5 \%$ e $49,4 \%$
} 
Tabela 1 - Condições Ocupacionais, por Raça. Salvador - 2017 e 2018*

\begin{tabular}{|c|c|c|c|c|}
\hline \multirow{2}{*}{ Condições Ocupacionais } & \multicolumn{4}{|c|}{ Cor ou Raça } \\
\hline & Total & Brancos & Pardos & Pretos \\
\hline $\begin{array}{l}\text { Desocupação entre as pessoas de } \\
14 \text { anos ou mais de idade }\end{array}$ & 19,2 & 12,8 & 21,3 & 19,1 \\
\hline $\begin{array}{l}\text { Trabalhadores sem instrução ou } \\
\text { com o fundamental incompleto } \\
\text { entre as pessoas de } 14 \text { anos ou } \\
\text { mais ocupadas }\end{array}$ & 32,7 & 19,2 & 33,3 & 36,4 \\
\hline $\begin{array}{l}\text { Trabalhadores com instrução } \\
\text { superior completo entre as } \\
\text { pessoas de } 14 \text { anos ou mais } \\
\text { ocupadas }\end{array}$ & 18,4 & 40,9 & 16,2 & 13,3 \\
\hline $\begin{array}{l}\text { Trabalhadores informais entre as } \\
\text { pessoas de } 14 \text { anos ou mais } \\
\text { ocupadas }\end{array}$ & 34,2 & 30,8 & 34,9 & 34,0 \\
\hline $\begin{array}{l}\text { Trabalhadores domésticos entre } \\
\text { as pessoas de } 14 \text { anos ou mais } \\
\text { ocupadas }\end{array}$ & 7,4 & 4,0 & 6,4 & 9,4 \\
\hline $\begin{array}{l}\text { Empregadores entre as pessoas } \\
\text { de } 14 \text { anos ou mais ocupadas }\end{array}$ & 3,2 & 10,1 & 2,1 & 2,3 \\
\hline $\begin{array}{l}\text { Rendimento médio mensal no } \\
\text { trabalho principal das pessoas de } \\
14 \text { anos ou mais (em reais) }\end{array}$ & 2.252 & $4 \cdot 351$ & 2.051 & 1.520 \\
\hline
\end{tabular}

Fonte: IBGE. Pesquisa Nacional por Amostra de Domicílios Contínua, primeiro trimestre de 2017 e primeiro trimestre de 2018 . Tabulações especiais efetuadas pela autora. *Os dados relativos à desocupação e renda se referem ao primeiro trimestre de 2018. Os demais ao primeiro trimestre de 2017.

Como os dados dessa tabela deixam patente, a taxa de desemprego é mais elevada entre os negros que entre os brancos. Trabalhadores com instrução de nível superior e empregadores predominam nesse segundo grupo, enquanto os ocupados com baixo nível de instrução, os trabalhadores informais e os trabalhadores domésticos são mais frequentes entre os negros. Os brancos auferem rendimentos médios no trabalho principal que chegam a mais que o dobro dos ocupados que se autodeclaravam pardos e a quase três vezes aos 
daqueles que se autodeclaravam pretos, o que se reflete sobre as condições de vida e de moradia desses contingentes e sobre os padrões locais de segregação.

Com a metodologia desenvolvida pelo Observatório das Metrópoles e a utilização dos microdados dos Censos de 2000 e de 2010, tornou-se possível identificar a dimensão racial desses padrões. Privilegiadas em termos da infraestrutura e serviços urbanos, das oportunidades de obtenção de emprego e renda e de outros recursos, a área Central e a Orla Atlântica constituem os espaços residenciais onde se concentra a parcela branca da população, enquanto o Miolo e o Subúrbio Ferroviário, que apresentam condições mais precárias de habitabilidade, menor disponibilidade de infraestrutura e serviços e carência de oportunidades de trabalho e de amenidades, abrigam predominantemente a parcela negra da população.

Figura 3 - Concentração Residencial dos Brancos. Salvador - 2010

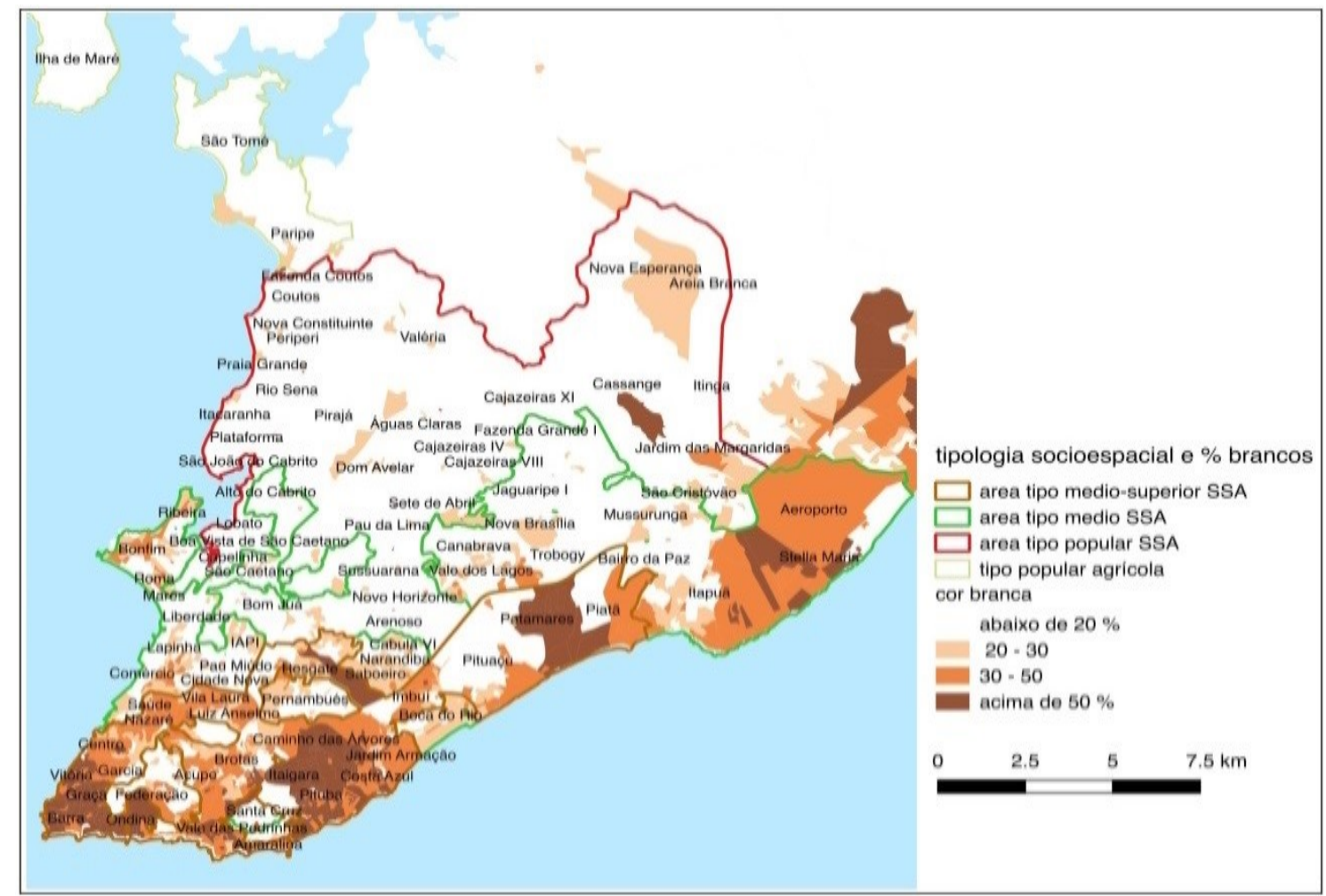

Fonte: IBGE. Censo Demográfico, 2010. Tabulações especiais efetuadas pela autora. 
Figura 4 - Concentração Residencial dos Pardos. Salvador - 2010

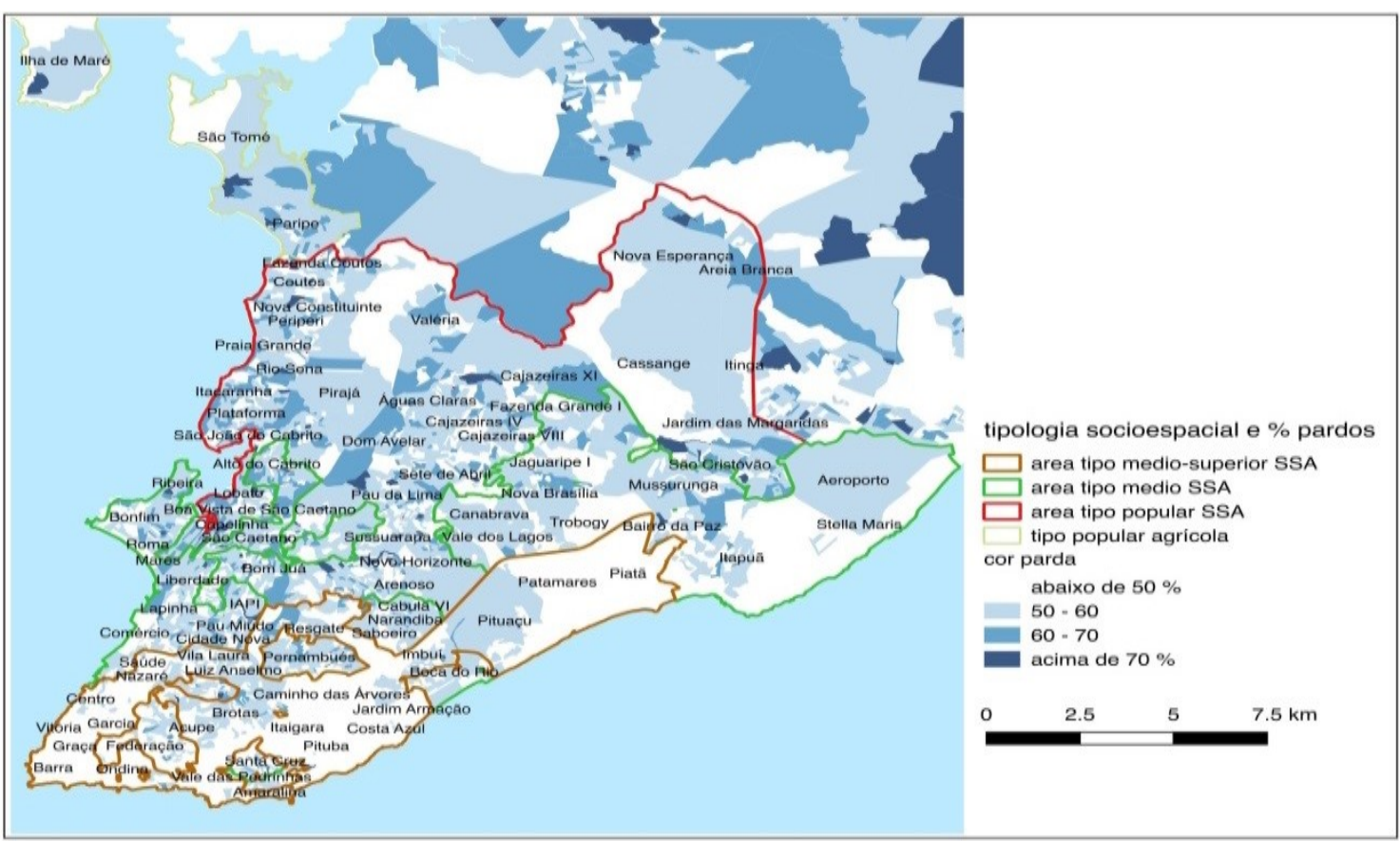

Fonte: IBGE. Censo Demográfico (2010)

Figura 5 - Concentração Residencial dos Pretos. Salvador - 2010

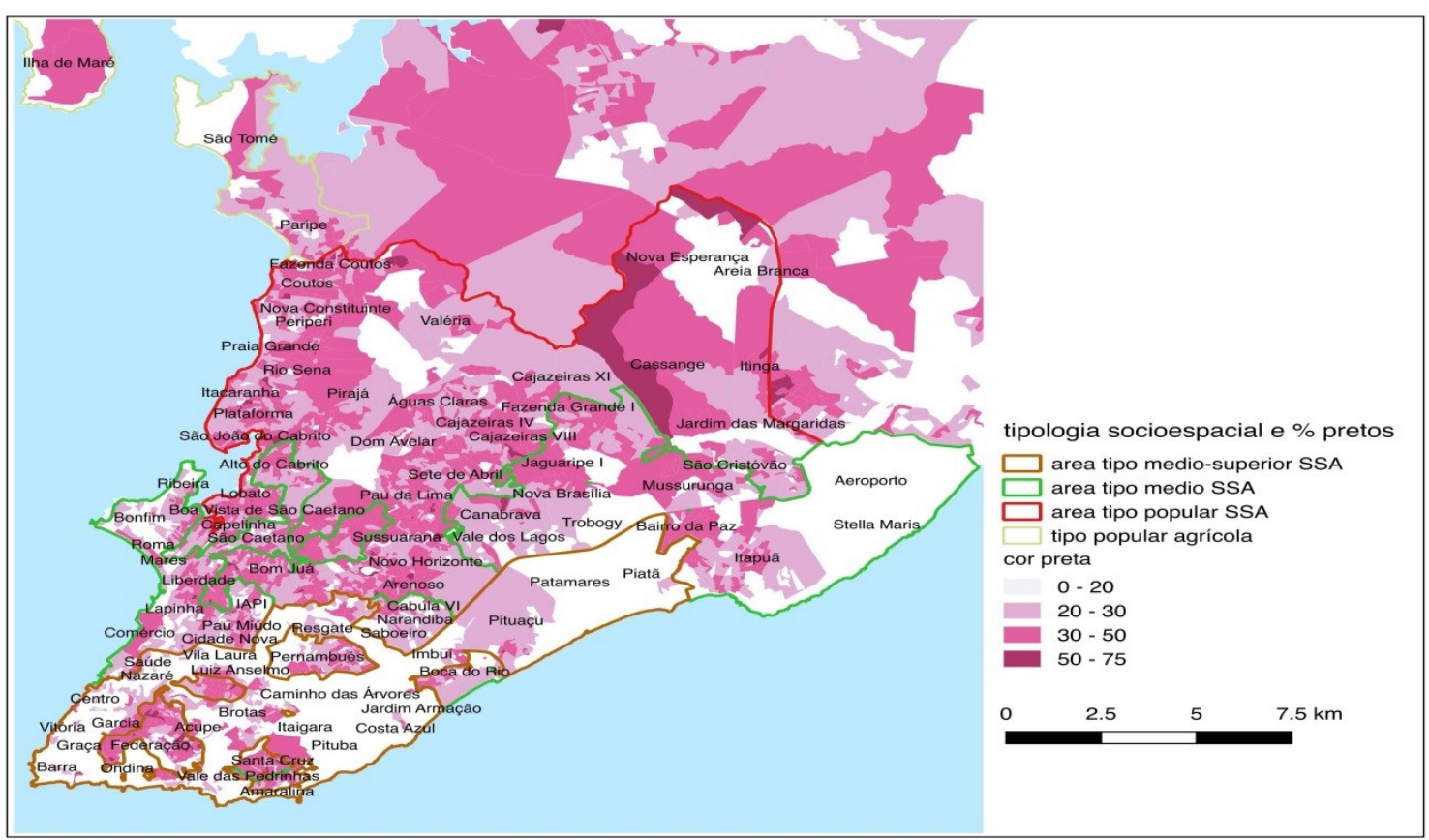

Fonte: IBGE. Censo Demográfico (2010)

Além disso, informações relativas à composição racial dos diferentes tipos de área encontradas na cidade mostram que os brancos se concentram nas áreas classificadas como 
de tipo superior ou médio superior, enquanto os negros predominam, principalmente, naquelas classificadas como de tipo popular e popular inferior. ${ }^{4} \mathrm{~A}$ parcela de brancos se encontra bastante sobre-representada nas áreas de tipo médio superior e, especialmente, nos seus locais mais elitizados, como a Barra, a Graça, Pituba, Itaigara/Caminho das Árvores/lguatemi e Horto Florestal, assim como em Vilas do Atlântico, condomínio residencial situado no município vizinho de Lauro de Freitas e já conurbado com Salvador, onde se localizam numerosos condomínios horizontais fechados 5 . Já a grande maioria dos negros, historicamente explorados, discriminados e pauperizados, se aglomera, como seria de esperar, nas áreas de tipo popular e popular inferior, em ocupações e loteamentos irregulares. Ocupações e loteamentos situados em pequenos interstícios do espaço central do território urbano, a exemplo do Calabar, do Engenho Velho da Federação, Nordeste de Amaralina, Alto de Santa Cruz e Boca do Rio, de ocupação mais antiga, nas periferias do Miolo e do Subúrbio, em bairros como Cajazeiras, Fazenda Grande, Sussuarana, Coutos, Plataforma, Paripe e Periperi, ou nos limites de Salvador com alguns municípios vizinhos. ${ }^{6}$

4 O Censo de 2000 permitiu a elaboração de uma tipologia mais refinada, distinguindo as áreas de tipo superior (mais elitizadas), daquelas de tipo médio superior, de tipo popular e de tipo popular inferior. Isto foi inviabilizado no censo de 2010, em decorrência de mudanças na metodologia e de uma redução das áreas de ponderação pelo IBGE. Contudo, abordando a segregação residencial e suas relações com a questão racial com base nos dados de 2000, Inaiá M. M. de Carvalho e Vanda de Sá. Barreto (2007) constataram que nas áreas do tipo superior residiam 64,8 dos auto-declarados brancos, 27,5 dos pardos e apenas 6,5 dos pretos. Em contrapartida, nas áreas de tipo popular inferior $13,7 \%$ dos moradores eram brancos, 60,9\% pardos e $23,3 \%$ pretos.

5 Com base nos dados do mesmo Censo, Antonia dos Santos Garcia também registrou esse tipo de distribuição, assinalando como os brancos representavam, de um lado, 69,4\% dos moradores no Itaigara, 67,0\% na Pituba, $71,7 \%$ na Barra/Barra Avenida, e 71,9\% na Graça, áreas mais elitizadas da cidade. Em contrapartida os negros predominavam em bairros precários e normalmente periféricos, constituindo $84,7 \%$ dos residentes da Fazenda Grande, $85,2 \%$ da Mata Escura, $85,3 \%$ de Pirajá, $86,1 \%$ do Bairro da Paz, $90 \%$ de Valéria e $90,2 \%$ do Nordeste de Amaralina.

6 Com base nos dados do mesmo Censo, Antonia Garcia também registrou esse tipo de distribuição, assinalando como os brancos representavam, de um lado, 69,4\% dos moradores no Itaigara, 67,0\% na Pituba, $71,7 \%$ na Barra/Barra Avenida, e 71,9\% na Graça, áreas mais elitizadas da cidade. Em contrapartida os negros predominavam em bairros precários e normalmente periféricos, constituindo $84,7 \%$ dos residentes da Fazenda Grande, $85,2 \%$ da Mata Escura, 85,3\% de Pirajá, 86,1\% do Bairro da Paz, 90\% de Valéria e $90,2 \%$ do Nordeste de Amaralina. 


\section{Segregação e "efeito território"}

Fica patente, portanto, que a raça não constitui uma categoria pouco significativa na constituição dos padrões de segregação residencial, ainda que não seja autoevidente e apresente uma dimensão moderada no caso de Salvador e de outras cidades brasileiras, (conforme já constatado por Edward E. Telles), acentuada nas áreas superiores, mas bastante reduzida nas áreas populares, onde os pobres e o negros estão concentrados. Além disso, essa concentração parece contribuir para a reprodução das desigualdades raciais, na medida em que a aglomeração dos grupos despossuídos e majoritariamente negros em grandes áreas homogêneas e precárias aumenta a gravidade dos seus problemas, com uma superposição de carências, uma deterioração das condições de vida e uma ampliação da sua vulnerabilidade em termos sociais e civis, conforme observado na capital baiana.

No que tange à educação, por exemplo, problemas como os baixos níveis de escolaridade da população, a precária qualidade do ensino e as taxas de atraso e evasão escolar representam marcas básicas da cidade, mas se diferenciam conforme o padrão de ocupação do espaço urbano, sendo particularmente desfavoráveis, como seria de esperar, nos bairros populares do Centro, do Miolo e do Subúrbio, assim como nos poucos enclaves de baixa renda que conseguiram se consolidar e persistem na Orla Atlântica. ${ }^{7}$ Decorrentes de um complexo conjunto de fatores, confirmando as observações da literatura apresentada no início do presente texto, essas desigualdades não estão dissociadas das condições do sistema de ensino e de sua distribuição no espaço urbano. e à maioria da população) e de sua distribuição e diferenciação no espaço urbano.

\footnotetext{
7 Até a década de 1960 existiam diversas ocupações irregulares no espaço central e na Orla Atlântica de Salvador. Nas décadas seguintes, porém, a velha capital passou por um intenso processo de crescimento e modernização econômica, populacional e urbana, associado à implantação de plantas industriais (voltadas à produção de insumos básicos e bens intermediários) em municípios vizinhos que passaram a constituir a sua atual região metropolitana. Nessa fase, comprometida com uma modernização excludente e com os interesses do capital imobiliário, a prefeitura de Salvador, que detinha a maioria das terras do município, efetuou uma reforma urbana que transferiu para (umas poucas) mãos privadas a propriedade das mesmas, inviabilizando mecanismos tradicionais de acesso ao solo e à moradia por parte das camadas de menor renda. Extirpou do tecido urbano mais valorizado um conjunto significativo de assentamentos da população mais pobre, que ocupava tradicionalmente os fundos (até então pouco accessíveis) dos números vales de Salvador, onde foram implantadas novas avenidas; erradicou ocupações populares localizadas na Orla marítima, área reservada ao turismo, outro componente básico da estratégia de crescimento e modernização da cidade, contribuindo decisivamente ao lado do capital imobiliário, para a conformação do atual padrão de segregação.
} 
Conforme assinalado nas páginas iniciais deste trabalho, diversos pesquisadores têm constatado como a qualidade dos estabelecimentos integrantes do referido sistema (e, mais precisamente, das escolas públicas, que atendem às camadas populares e à maioria dos residentes), geralmente é mais desfavorável nas áreas segregadas onde se encontra a população de menor renda.

No caso de Salvador, embora esses estabelecimentos persistam concentrados sobretudo na área central, a expansão do ensino fundamental nos últimos anos levou escolas a praticamente toda a cidade, ainda que, na maioria dos casos, elas se caracterizem pela precariedade de sua infraestrutura, não dispondo de biblioteca, quadra de esportes, laboratório de ciências ou laboratório de informática. Os estabelecimentos de ensino médio estão localizados notadamente na área central e na Orla Atlântica e a qualidade do conjunto de estabelecimentos se diferencia significativamente de acordo com sua distribuição. Conforme a pesquisa de Costa Silva (2016). A grande maioria das escolas que poderiam ser consideradas como relativamente bem equipadas, dispondo simultaneamente de biblioteca, laboratório de ciências e laboratório de informática, está localizada nos espaços privilegiados da cidade. Os indicadores relativos à formação do corpo docente, à relação professor/aluno e à disponibilidade de suporte pedagógico também são mais favoráveis a esses estabelecimentos. Aqueles com elevada proporção de alunos/professor, por exemplo, praticamente inexistem na área central e na Orla, concentrando-se nos bairros pobres do Miolo e do Subúrbio. Como se sabe, essa proporção se reflete no cotidiano das escolas, com efeitos adversos sobre as possibilidades de atenção, acompanhamento e estímulo aos estudantes e sobre a formação de laços subjetivos entre professores e alunos, com impactos relevantes sobre o seu rendimento e possibilidades de sucesso em termos educacionais.

A distribuição de coordenadores pedagógicos é também bastante desigual. As unidades situadas nas coordenações regionais do Subúrbio I, Subúrbio Il e de Cajazeiras, por exemplo, possuíam coordenadores em apenas 21\%, 14\% e 13\% das suas escolas. Já na coordenação regional do Centro, a proporção daquelas que dispunham desses profissionais nos seus quadros chegava a 67,5\% em 2010, conforme o levantamento da Secretaria Municipal de Salvador (COSTA SILVA, 2016, p. 178). Além disso, em resposta a uma indagação da Prova Brasil sobre o futuro escolar dos alunos, os professores deixaram claras as suas baixas expectativas quanto ao desempenho e ao futuro dos seus discentes. Mais da metade deles considerava que os alunos não iriam além do ensino fundamental e apenas 
$12,9 \%$ que chegariam ao ensino superior. Não deixam de ser respostas realistas, mas elas expressam, (igualmente), a visão dos docentes sobre as dificuldades de aprendizagem dos alunos, que atribuíam, sobretudo, a fatores como a falta de acompanhamento e assistência da família na execução das tarefas escolares, o desinteresse e a carência de esforços no sentido de um melhor desempenho, a influência do meio em que vivem, a indisciplina nas salas de aula e o baixo nível cultural dos pais. Problemas institucionais e pedagógicos foram mencionados em último lugar e os professores acreditavam ter pouco poder para enfrentar as dificuldades em discussão.

Levando em conta que é justamente nos espaços mais pobres que a educação das crianças e dos jovens demanda uma maior qualificação e cuidado, a dimensão e as desigualdades educacionais no espaço urbano não são de surpreender. Nas áreas de tipo popular e popular inferior, que predominam no Subúrbio e no Miolo, por exemplo, um atraso escolar de dois anos entre os sete e quinze anos era quatro ou cinco vezes mais elevado e o abandono escolar entre os quinze e dezessete anos de cinco a seis vezes superior ao que se registrava nas áreas de tipo médio superior localizados na Orla.

Os impactos dessa realidade são patentes e puderam ser observados, por exemplo, em pesquisa realizada por Santos (2018) sobre os efeitos do lugar no acesso dos jovens à estrutura de oportunidades em dois bairros populares de Salvador: o Nordeste de Amaralina/Santa Cruz, relativamente central e próximo a áreas mais abastadas e aos diversos equipamentos e serviços urbanos, e o de Nova Brasília, localizado na periferia mais distante e desassistida da cidade. Mesmo no primeiro desses bairros, o acesso a níveis mais elevados de ensino era bastante restrito e, nos raros casos em que ocorria, estava associado a condições diferenciadas em termos de incentivo da família, participação em projetos sociais e, principalmente, esforço pessoal dos jovens, envolvendo, entre outros aspectos, o deslocamento do bairro para as áreas mais afluentes da cidade em busca de escolas mais qualificadas. O depoimento de um jovem, que conseguiu ingressar no curso de Comunicação da Universidade Federal da Bahia mediante um extraordinário esforço pessoal e a política de cotas raciais e sociais dessa universidade, é bastante ilustrativo a esse respeito.

"Prá você ter ideia, eu passei no Thales de Azevêdo (um dos melhores colégios públicos de Salvador, localizado no Costa Azul, bairro da Orla), pela seleção e ia e voltava andando, porque tinha as pendências (dificuldades financeiras) em casa e eu saia daqui cedo, nove da manhã, estudava à tarde, chegava lá umas 9:30, 
relaxava e ia estudar, ficava lá o dia todo. Eu sempre tive isso na minha mente, se eu quisesse alguma coisa tinha que ir buscar, porque eles não querem ... Aqui tem escolas, mas não tem incentivo, estímulo, professores não têm condição mínima de trabalho, para você ter ideia" (Jovem negro de 22 anos, morador do Nordeste de Amaralina/Santa Cruz, SANTOS, 2018, p. 167).

Sem que o sistema escolar lhes propicie a aprendizagem e o avanço necessários para - alcance das competências e credenciais educacionais cada vez mais exigidas para a conquista de melhores condições de integração, ocupação e mobilidade social, os moradores dos espaços populares também são penalizados pela distribuição dos estabelecimentos comerciais e de serviços, e das oportunidades de emprego e renda no espaço urbano, especialmente em uma cidade onde a economia está basicamente ancorada nas atividades do setor terciário, como Salvador. Os padrões de urbanização e a concentração de renda que marcaram o desenvolvimento de países como o Brasil têm levado a uma enorme concentração das oportunidades de emprego e renda no centro das cidades e nos seus bairros afluentes. Com isso, a distribuição dos estabelecimentos e dos empregos no espaço urbano termina por se somar às desvantagens educacionais, à estreiteza das redes sociais (reduzidas por um relativo isolamento e limitadas, por vezes, a vizinhos e famílias nas mesmas condições de vulnerabilidade), e à discriminação racial e social contra os residentes em bairros percebidos como degradados e violentos, reforçando os efeitos adversos das condições de segregação.

No caso de Salvador, onde os problemas ocupacionais são especialmente acentuados, dados do Ministério do Trabalho/RAIS sobre a localização dos estabelecimentos empregadores em 2010, sistematizados por regiões administrativas e adaptados à tipologia sócio espacial antes mencionada, deixam patente como os mesmos se encontram concentrados na área central e na Orla Atlântica, sendo bastante escassos nas regiões densamente povoadas do Miolo, do Subúrbio e dos limites da capital com os municípios vizinhos da sua região metropolitana.

Conforme constatado por Borges e Carvalho (2017), isto se traduzia em uma concentração de empregos formais de modo bastante desproporcional à distribuição da população no território urbano, como se observa pelos dados da Tabela II, em especial através do indicador postos de trabalho/mil habitantes por região administrativa (RA). $\mathrm{Na}$ região Centro, área de ocupação mais antiga, que constituiu o centro administrativo e econômico da cidade até à década de 1970, o número de postos formais era superior ao da 
própria população moradora, configurando a situação comum de um centro urbano que, em muitos trechos, já perdeu sua função residencial. A persistência dessa concentração beneficia os moradores das áreas próximas ou mais bem servidas de transportes para essa região, em detrimento daqueles residentes nas periferias. No restante do território, os postos formais de Salvador se localizam, sobretudo, nos espaços de tipo médio e médio superior da Orla Atlântica, habitados predominantemente pelas camadas de média e alta renda. Essa concentração de empregos, sobretudo nas regiões administrativas do Centro, de Boca do Rio e de Brotas - as três maiores "bacias" de emprego formal da cidade - ocorre em quase todas as atividades, enquanto a RA de Itapuã se destaca pela concentração de empregos públicos no Centro Administrativo.

A concentração espacial dos estabelecimentos é especialmente acentuada nas atividades de serviços, que geram a maior parte dos postos formais de Salvador; $65 \%$ deles estão localizados em apenas quatro das dezoito regiões administrativas (as da Pituba/Costa Azul, Centro, Barra e Brotas, que podem ser classificadas como do tipo médio e médio superior) e $80 \%$ em sete delas, quando computadas as regiões administrativas do Rio Vermelho, Itapuã e Boca do Rio/Patamares, de composição similar. Além disso, esses espaços são igualmente privilegiados ao concentrar todos os tipos de postos de trabalho, considerados os grupos ocupacionais e os níveis de remuneração. São "bacias de emprego" para todos os perfis de trabalhadores, o que contribui para ampliar o seu poder de atração de novos empreendimentos, de mais postos de trabalho e do contingente de ocupados. Assim, não é surpreendente que os referidos espaços sediassem $75,5 \%$ dos postos formais da cidade, e apenas $37,1 \%$ de sua população.

A outra face dessa distribuição ficava visível nas regiões administrativas correspondentes a espaços de tipo popular e popular inferior, como Valéria, Pau da Lima, São Caetano, Tancredo Neves, Subúrbio Ferroviário, Cajazeiras e as llhas, ocupadas predominantemente pelos pobres e pelos negros. Nessas outras sete regiões administrativas residiam 42,9\% dos habitantes de Salvador em 2010, mas aí eram encontrados apenas 14,1\% dos empregos formais do município, revelando a presença de mercados de trabalho locais restritos, elevados níveis de informalidade (Tabela 2). Sobre a qualidade dos postos ofertados nos referidos espaços, aliás, pode ser mencionado um dos depoimentos coletados no decorrer da pesquisa de Santos (2018, p. 168), onde um dos entrevistados compara as 
condições desses postos com aqueles que prevaleceriam nas áreas centrais e afluentes da cidade.

"Tem muita diferença, porque a maioria dos trabalhos oferecidos no bairro são trabalhos que têm uma carga horária muito grande, tem pessoas que entram no supermercado para trabalhar 7 horas e saem 10 horas da noite" (Jovem negro, morador do Nordeste de Amaralina/Santa Cruz, atualmente estuda na Universidade Federal da Bahia).

Tabela 2 - População e Postos de Trabalho por Regiões Administrativas Salvador - 2010

\begin{tabular}{|c|c|c|c|c|c|}
\hline \multirow{2}{*}{ Regiões Administrativas } & \multicolumn{2}{|c|}{$\begin{array}{c}\text { Pessoas } \\
\text { Residentes }\end{array}$} & \multicolumn{2}{|c|}{$\begin{array}{c}\text { Postos de } \\
\text { Trabalho }\end{array}$} & \multirow{2}{*}{$\begin{array}{c}\text { Postos de } \\
\text { Trabalho/mil } \\
\text { habitantes }\end{array}$} \\
\hline & $\mathbf{N}$ & $\%$ & $\mathbf{N}$ & $\%$ & \\
\hline \multicolumn{6}{|c|}{ De tipo predominantemente médio ou médio superior } \\
\hline Centro & 100.232 & 3,5 & 143.498 & 20,3 & $1.431,7$ \\
\hline Pituba-Costa Azul & 184.298 & 6,4 & 136.783 & 19,3 & 742,2 \\
\hline Barra & 95.348 & 3,3 & 46.856 & 6,6 & 491,4 \\
\hline Itapuã & 235.612 & 8,1 & 86.623 & 12,2 & 367,7 \\
\hline Boca do Rio-Patamares & 118.334 & 4,3 & 18.041 & 5,4 & 321,5 \\
\hline Brotas & 209.112 & 7,3 & 58.724 & 8,3 & 280,8 \\
\hline Rio Vermelho & 133.571 & 4,6 & 31.154 & 4,4 & 233,2 \\
\hline \multicolumn{6}{|c|}{ De tipo predominantemente médio/popular } \\
\hline Itapagipe & 172.921 & 6,0 & 23.163 & 3,3 & 134,0 \\
\hline Cabula & 170.113 & 5,9 & 21.516 & 3,0 & 126,5 \\
\hline Liberdade & 172.685 & 6,0 & 16.947 & 2,4 & 98,1 \\
\hline São Caetano & 212.648 & 7,3 & 16.235 & 2,3 & 76,3 \\
\hline \multicolumn{6}{|c|}{ De tipo predominantemente popular/popular inferior } \\
\hline Valéria & 65.073 & 2,2 & 10.698 & 1,5 & 164,4 \\
\hline Pau da Lima & 264.017 & 9,1 & 29.145 & 4,1 & 110,3 \\
\hline São Caetano & 212.648 & 7,3 & 16.235 & 2,3 & 76,3 \\
\hline Tancredo Neves & 245.230 & 8,5 & 18.284 & 2,6 & 74,6 \\
\hline Subúrbio & 290.017 & 10,0 & 19.949 & 2,8 & 68,8 \\
\hline Cajazeiras & 162.687 & 5,6 & 5.460 & 0,8 & 33,6 \\
\hline Ilhas & 6.434 & 0,2 & - & - & - \\
\hline
\end{tabular}

Fonte: MTE. RAIS/DIEESE/SETRE. Observatório do Trabalho. Conforme Borges e Carvalho (2017). *Como as áreas das regiões administrativas não se confundem exatamente com as das AEDS, a classificação de sua composição social é aproximada.

Conforme ressaltado anteriormente, essa "geografia de oportunidades", com a concentração dos postos de trabalho socialmente protegidos nos privilegiados espaços do 
tipo médio e médio superior, se soma aos impactos adversos de moradia em áreas populares, periféricas e segregadas (como a precariedade das escolas, a estreiteza das redes sociais, os preconceitos e discriminações de ordem social, racial e territorial) ${ }^{8}$, contribuindo para dificultar a incorporação produtiva dos seus residentes. Notadamente no caso dos jovens, dos negros, das mulheres, daqueles dotados de menor escolaridade e dos que somam alguns desses atributos, como os jovens negros do sexo masculino com poucos anos de estudo. Com isso, muitos dos referidos residentes terminam engrossando o contingente dos denominados nem/nem (distanciando-se das instituições integradoras básicas como a escola e o trabalho), ou mais expostos ao desemprego, à ocupação precária e à violência.

Dados das Pesquisas Nacionais por Amostra de Domicílios Contínua de 2017 e 2018, apresentados anteriormente, deixaram patente como os negros desfrutam de condições ocupacionais especialmente negativas em Salvador, sendo mais afetados pela desocupação, pela precariedade e pelos baixos níveis de remuneração que prevalecem no mercado de trabalho local. Quando o Censo de 2010 foi realizado, porém, o Brasil experimentava uma conjuntura mais favorável em termos econômicos e sociais, com um crescimento da economia e do emprego que beneficiou, sobretudo, os segmentos de base da pirâmide social, pelas oportunidades abertas pela ativação do mercado formal e pelo perfil da maior parte dos postos criados: postos de trabalho na construção civil (um espaço de entrada no mercado de trabalho de homens jovens menos escolarizados), no comércio e em serviços de apoio, onde se multiplicaram os empregos com remuneração em torno de um salário mínimo.

Ainda que isto se refletisse positivamente sobre o panorama ocupacional das grandes metrópoles brasileiras, como Salvador, os históricos problemas de ocupação e renda persistiram bastante acentuados na capital baiana. Notadamente entre os moradores (majoritariamente negros) das áreas de tipo popular e popular inferior, pois, conforme os

8 Como assinala Luiz Cesar Q. Ribeiro (2005), a discriminação contra "favelados" e moradores de outros espaços de tipo popular também pode ser interpretada como uma das formas de manifestação de preconceito e discriminação racial no Brasil (tal como a "boa aparência"), uma vez que o local de moradia expressa e reproduz a segmentação estamental da hierarquia social no país e o lugar do negro nessa hierarquia. É significativo que metade dos jovens entrevistados por Lícia Maria Souza dos Santos (2018, p. 176), na sua pesquisa tenha se reportado à necessidade de omitir o seu local de moradia para conseguir um emprego, fornecendo o endereço de parentes que residiam em áreas socialmente valorizadas da cidade. Conforme um desses entrevistados, "eu fui empregado assim, tenho certeza que se colocasse que sou residente daqui não teria conseguido. Sentimos o peso disso, se não dão oportunidades aos jovens daqui e depois perguntam por que os jovens estão no tráfico" (jovem negro, 23 anos, residente no Nordeste de Amaralina/Santa Cruz. 
indicadores apresentados (Tabela 3), a vulnerabilidade sócio-ocupacional também está associada ao seu local de moradia. A frequência de jovens com idade entre 16 e 29 anos de idade que não estudam, não trabalham e não procuram emprego (sendo por isso denominados como nem/nem), por exemplo, era normalmente mais elevada nas áreas de tipo popular do que naquelas de tipo médio e médio-superior, assim como a exposição ao desemprego, à informalidade da ocupação e à própria violência.

Tabela 3-Indicadores Ocupacionais por Raça. Salvador - 2010

\begin{tabular}{|c|c|c|c|c|}
\hline \multirow[b]{2}{*}{ Indicadores/Raça(1) } & \multirow[b]{2}{*}{ Município } & \multicolumn{3}{|c|}{ Áreas Segundo Tipologia } \\
\hline & & $\begin{array}{l}\text { Médio e } \\
\text { Médio- } \\
\text { Superior }\end{array}$ & Médio & Popular \\
\hline
\end{tabular}

Jovens que não estudam, não trabalham nem procuram emprego

\begin{tabular}{lcccc} 
Negros & 15,5 & 12,0 & 15,6 & 16,5 \\
Não Negros & 13,3 & 11,0 & 13,6 & 15,9 \\
\hline Taxa de desemprego & & & & \\
Negros & 14,0 & 8,2 & 13,8 & 16,2 \\
Não Negros & 9,3 & 5,5 & 10,2 & 14,5 \\
\hline Ocupados na informalidade & & & & \\
Negros & 42,6 & 38,6 & 42,0 & 44,5 \\
Não Negros & 37,2 & 33,2 & 38,8 & 42,3 \\
\hline
\end{tabular}

Fonte: IBGE. Tabulações especiais do Censo Demográfico de 2010. Conforme Borges e Carvalho, 2017.
(1) Em percentuais
(2) *Pardos e pretos, conforme classificação do IBGE.
(3) **Brancos, indígenas e amarelos, conforme classificação do IBGE.

Pois, na sociedade brasileira, que se transformou em uma das mais violentas do mundo, com um número de mortos por homicídios similar ou até superior ao de alguns países em guerra, a concentração da população em áreas homogêneas, precárias e desassistidas tem aumentado igualmente a sua vulnerabilidade civil com uma maior exposição à criminalidade, à violência e à morte precoce. Moradores de favelas e periferias convivem 
cotidianamente com essa realidade, que se traduz em restrições à mobilidade, toques de recolher, suspensão de aulas, tiroteios, balas perdidas e um grande número de homicídios, cuja maioria das vítimas é constituída por jovens pobres, negros e de baixa escolaridade.

Em Salvador, como em tantas outras cidades do país, o tráfico de drogas e outras formas de criminalidade têm se apropriado de vários desses espaços, articulando, a partir destes, sua atuação mais ampla no território da cidade, dominando os moradores locais e recrutando jovens pobres, predominantemente negros e sem perspectivas, para o consumo de drogas e para a delinquência, contribuindo para a deterioração dos padrões de sociabilidade e para o crescimento de violência nos espaços em questão.

De acordo com dados oficiais da Secretaria de Segurança Pública do Estado da Bahia, na metrópole baiana a geografia dos homicídios dolosos se encontra bastante articulada aos padrões de segregação, com a concentração em áreas do tipo popular localizadas geralmente no Miolo e no Subúrbio. Mais precisamente, em espaços como aqueles onde ficam as Áreas Integradas de Segurança Pública (AISP) correspondentes aos bairros de Lobato, Periperi, Liberdade, Valéria, Beiru/Tancredo Neves, Boca do Rio, São Caetano e Fazenda Grande do Retiro, conforme ressaltado por Casais Neto e Calasans (2017). Em espaços desse tipo, a taxa de homicídios/mil habitantes pode chegar a mais de 90 (Figura 4), decrescendo significativamente em áreas do tipo médio e médio superior como a Barra e o Rio Vermelho e chegando a zero em bairros mais afluentes como o Canela, a Graça, o Itaigara e o Caminho das Árvores. 
Figura 6 - Distribuição dos Homicídios - Salvador 2012. Fonte: Secretaria de Secretaria

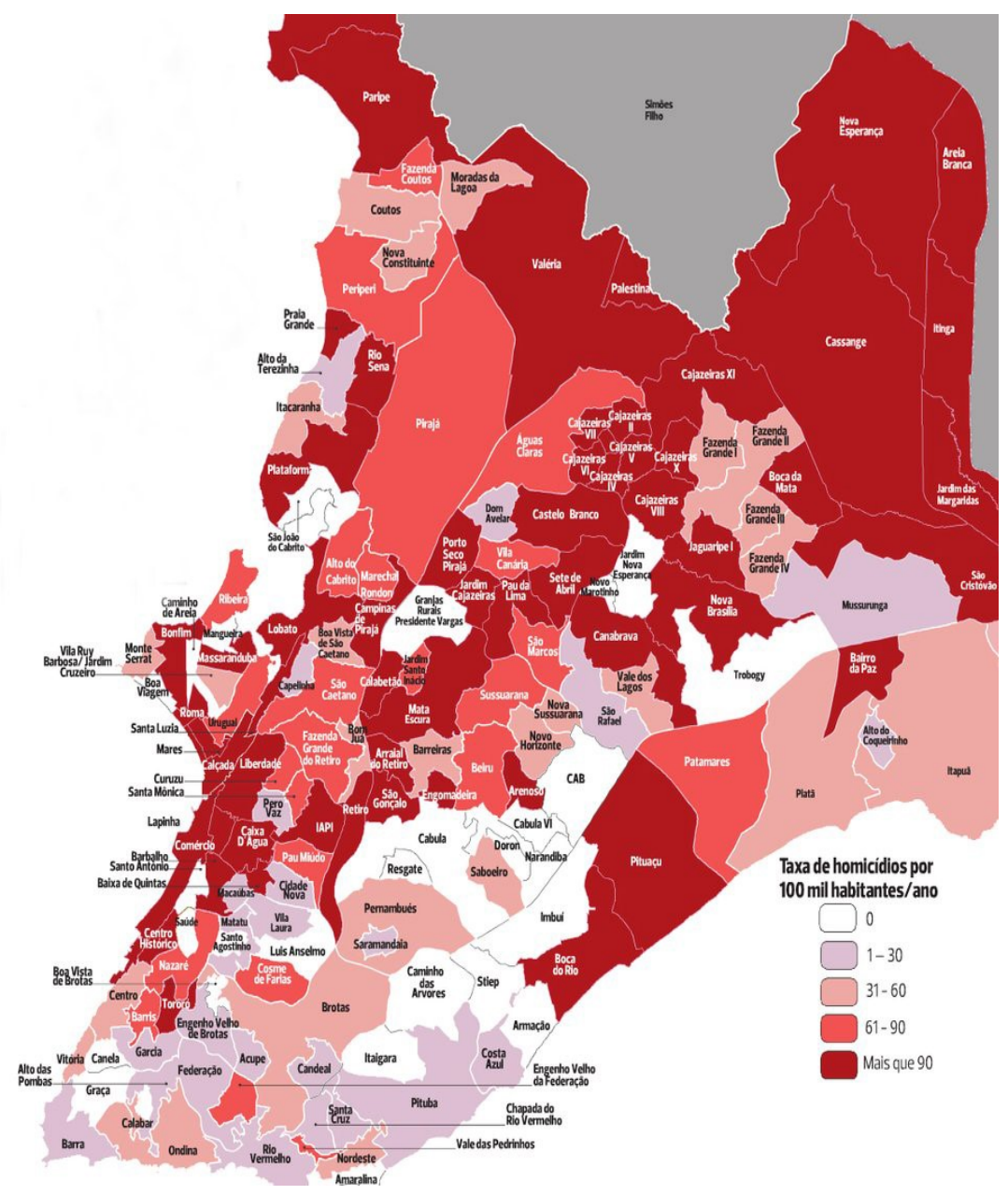

Pública e IBGE. Conforme Correio da Bahia (2012)

A distribuição do policiamento, porém, se dava de forma inversa à frequência dos homicídios. Como ressalta Carvalho (2018), a região que compreende os bairros da Graça, Barra e o Corredor da Vitória, reduto elitizado da parcela branca da população, onde havia ocorrido apenas três homicídios em 2012, contava com uma Delegacia Territorial, a $14^{\mathrm{a}}$, e uma companhia da Polícia Militar para cuidar da segurança dos seus 40.997 habitantes. Já os 374.013 moradores de 22 bairros populares de uma região que tem em seus extremos os bairros de Pernambués, Calabetão, Centro Administrativo da Bahia e Mata Escura, onde, em 2012, já havia morrido 79 pessoas, tinham direito igualmente a uma delegacia, a $11^{\text {a }}$ DT. Em uma outra área crítica da cidade, que abrangia nove bairros pobres e predominantemente negros entre São Caetano e a Fazenda Grande, com um contingente de 216.260 habitantes e um registro de 51 vítimas fatais de violência, contava também com uma única delegacia, a $4^{\text {a }}$ DT, e uma companhia de Polícia Militar, conforme dados oficiais divulgados em 
reportagem do jornal Correio da Bahia. Ademais, não se pode ignorar como a violência policial também se abate frequentemente sobre a juventude negra residente nas áreas e periferias de tipo popular, conforme igualmente ressaltado em vários depoimentos coletados por Santos (2018, p. 160.174), a exemplo dos reproduzidos a seguir.

"[...] uma vez me pegaram [...] botei a mão na cabeça, chutaram minha perna, me botaram de cabeça para baixo... é que eles não se contentaram em ver o cara preto... falaram que se eu não me entregasse, [...]" (Jovem negro de 16 anos, estudante, relatando uma abordagem da polícia no Nordeste de Amaralina).

"[...] a violência está em todo lugar, sim. Porém aqui na favela ela é muito maior e mais suja. A polícia tem carta branca para forjar a morte de qualquer jovem aqui no bairro. A violência aqui no bairro é consequência do descaso do Estado para com a população" (Jovem negro, estudante, morador do Nordeste de Amaralina/Santa Cruz).

\section{Finalizando}

Outros indicadores poderiam ser agregados à presente discussão. Em Salvador, como em outras grandes cidades brasileiras, equipamentos culturais e de lazer, como teatros, museus, parques públicos e quadras esportivas, se encontram quase que absolutamente concentrados na "área nobre" da cidade. Além disso, os padrões de ocupação do solo urbano e de segregação, a "cultura do automóvel" e a carência de políticas direcionadas a uma maior descentralização das atividades e de um sistema de transporte público mais integrado e eficiente vêm ampliando os problemas de mobilidade e penalizando especialmente os contingentes pobres, negros e moradores dos bairros periféricos e mais distantes, pontos de partida da grande maioria das viagens em direção ao trabalho e aos equipamentos e serviços urbanos. Viagens realizadas em um sistema de transportes de muito baixa qualidade, com uma elevação dos custos monetários e não monetários dos deslocamentos, acabam obrigando uma parcela não desprezível dos referidos moradores, inclusive, a realizar longos deslocamentos a pé ou a permanecer relativamente confinados nos seus espaços de moradia.

Fica patente, portanto, uma estreita articulação entre as desigualdades raciais e os padrões de apropriação e fruição do espaço urbano, na medida em que o espaço social, as hierarquias e as desigualdades também se traduzem no território. Os segmentos que se encontram no topo do espaço social e de suas hierarquias, em decorrência do capital econômico, social e cultural de que são detentores, têm a capacidade de se apropriar dos 
espaços mais seletivos e privilegiados e dos bens e serviços mais raros e desejáveis aí instalados. Já aqueles que estão na base da estrutura e das hierarquias são mantidos à distância desses espaços e levados a se instalar em áreas mais desfavoráveis, distantes e desassistidas, onde carências de várias ordens se conjugam e se reforçam, agravando a despossessão.

Como foi visto ao longo do presente trabalho, no caso do Brasil e de Salvador, isto vem afetando especialmente a parcela negra da população, historicamente explorada, discriminada e majoritariamente pauperizada. Por isso, cabe ampliar os debates sobre os fenômenos abordados no presente trabalho e lutar por sua transformação, contribuindo para o combate às desigualdades raciais e para a construção de cidades mais justas e democráticas no nosso país.

\section{Referências}

AINSWORTH, J. L. Why does it take a village. Mediation of neighborhood effects on educational achievemnt. The Universityof North Carolina Press, 2002.

ANDRADE, Luciana T; SILVEIRA, Leonardo S. Efeito Território. Explorações em torno de um conceito sociológico. Civitas, Porto Alegre, v. 13, n. 2, mai-ago., 2013.

BORGES, Ângela M. C.; CARVALHO, Inaiá M. M. de. Revisitando os Efeitos de Lugar: segregação e acesso ao mercado de trabalho em uma metrópole brasileira. Caderno CRH, Salvador, v. 30, n. 79, 2017.

BOURDIEU, Pierre. Efeitos de Lugar In: BOURDIEU, Pierre (Coord.) A Miséria do Mundo. 3. ed. Petrópolis: Ed. Vozes, 1997.

CALDEIRA, Teresa P. do R. Cidade dos muros: crime, segregação e cidadania em São Paulo. São Paulo: EDUSP, 2000.

CARVALHO, Inaiá M. M. de; BARRETO, Vanda S. Segregação residencial, condição social e raça em Salvador. Cadernos Metrópoles, São Paulo, n. 18, 2007.

CARVALHO, Inaiá M. M. de; PEREIRA, Gilberto C. Como Anda Salvador. 2. ed. Salvador: Editora da Universidade Federal da Bahia, 2008.

CARVALHO, Inaiá M. M. de; PEREIRA, Gilberto C. Salvador: Transformações na Ordem Urbana. In: RIBEIRO, Luiz Cesar Q; RIBEIRO, Marcelo Gomes (Ed.) Metrópoles Brasileiras, Síntese da Transformação na Ordem Urbana, 1980 a 2010. Rio de Janeiro: Letra Capital; Observatório das Metrópoles, 2014.

CARVALHO, Inaiá M. M. de. Segregação, vulnerabilidade e desigualdades sociais e urbanas. Salvador, 2018 (inédito). 
CASAIS NETO, Rafael; CALAZANS, Márcia E. Necropolítica racial criminal em uma capital do Nordeste do Brasil: uma análise criminológica dos homicídios em Salvador. PIXO, Revista de Arquitetura, Cidade e Contemporaneidade, Salvador, v. 1, n. 3, 2017.

COSTA SILVA, Diogo Reys da. Vazios Ocultos: dinâmica urbana e acesso à educação básica em Salvador. Dissertação (Doutorado) - Faculdade de Filosofia e Ciências Humanas, Universidade Federal da Bahia, Salvador, 2016.

GARCIA, Antonia dos Santos. Desigualdades Raciais e Segregação Urbana em Antigas Capitais: Salvador, cidade D'Oxum e Rio de Janeiro: Cidade de Ogum. Rio de Janeiro: Observatório das Metrópoles; Letra Capital, 2009.

GOMES, Sandra; AMITRANO, Cláudio. Local de moradia na metrópole e vulnerabilidade ao emprego e desemprego. In: MAROUES, Eduardo; TORRES, Haroldo (Org.). São Paulo, Segregação, Pobreza e Desigualdades Sociais. São Paulo: Ed. SENAC, 2005.

JARGOWSKY. P. A. Take the Money and run: economic segregation In U. S. metropolitan áreas. American Sociological Rewiew, n. 61, p. 984-998, 1996. Disponível em: http:/www.jstor. org/stabel/2096304. Acesso em: 14 out. 2014.

KATZMAN, Rubem; RETAMOSO, A. Segregacion espacial, empleo y pobreza em Montevideo. Revista CEPAL, v. 85, p. 131-148, 2005.

KATZMAN, Rubem; RETAMOSO, Alejandro. Segregacion Residencial en Montevideo. Desafios para la Equidad Educativa. Colección Monitor social, Santiago de Chile, n. 7, Comission Economica para America Latina y Caribe, 2006.

MARQUES, Eduardo; TORRES, Haroldo. (Org.). São Paulo: segregação, pobreza e desigualdades sociais. São Paulo: Ed. SENAC, 2005.

MOLINATTI, Florencia. Segregacion residencial y inserção laboral en la ciudad de Cordoba. EURE, Santiago de Chile, v. 39, n. 117, 2013.

PRETECEILLE, Edmond. La segregacion ethno raciale at-elle augmenté dans la metrópole parisiense? Revue Française de Sociologie, Paris, v. 50, n. 3, 2003.

RIBEIRO, Luiz Cesar Q.; KAZTMAN, Ruben. A cidade contra a escola. Segregação urbana e desigualdades educacionais nas grandes cidades da América Latina. Rio de Janeiro: Letra Capital, 2008.

RIBEIRO, Luiz Cesar Q. et al (Org.). Desigualdades urbanas, desigualdades escolares. Rio de Janeiro: Letra Capital: Observatório das Metrópoles, 2010.

RIBEIRO, Luiz Cesar Q. Segregação residencial e segmentação social: o "efeito vizinhança" na reprodução de pobreza nas metrópoles brasileiras. Cadernos Metrópole. São Paulo, n. 13, $1^{\circ}$ semestre, 2005.

SABATINI, Francisco; CÁCERES, O.; CERDA, J. Segregação residencial nas principais cidades chilenas: tendências das últimas três décadas e possíveis cursos de ação. Espaço 8 Debates -Revista de Estudos Regionais e Urbanos, São Paulo, v. 24, n. 45, 2004. 
SABATINI, Francisco; WORMALD, Guilhermo; RASSA, Alejandra (Ed.). Segregación de la Vivenda Social: ocho conjuntos en Santiago. Concepcion y Talca. Santiago: Instituto de Estudios Urbanos y Territoriales de PontificiaUniversidad Católica de Chile, 2013.

SANTOS, Lícia Maria Souza dos. As fronteiras do lugar na vida dos jovens: um estudo nos bairros do Nordeste de Amaralina e de Nova Brasília em Itapuã em Salvador-Bahia. Tese (Doutorado) Faculdade de Filosofia e Ciências Humanas, Universidade Federal da Bahia, Salvador, 2018.

SASSEN, Saskia. The Global City: New York, Tkyo, New Jersey: Princeton University Press, 1991.

SERAVI, Gonzalo A. Mundos aislados: segregación urbana y desigualdade em La Ciudad de Mexico. EURE, Santiago de Chile, v. XXXIV, n. 103, 2008.

SHAPIRA, M. FR. P. Segregação, fragmentação, sucessão: a nova geografia social de Buenos Aires. Novos Estudos CEBRAP, São Paulo, n. 56, 2000.

SMALL, Mario L.; NEWMAN, Katherine. Urban poverty after The Truly Desavantaged. The rediscovery of the family, the neighborhood and culture. Annual Rewiew of Sociology, v. 27, p. 23$45,2001$.

SOLIS, P; Puga, I. Efectos del nivel socioeconomico de la zona residencial sobre el proceso de estratificación social en Monterrey. Estudios Demograficos y Urbanos, Ciudad de Mexico, v. 26, n. $2,2011$.

TELLES, Edward E. Racismo à Brasileira, uma nova perspectiva Sociológica. Rio de Janeiro: Relume Dumará; Fundação Ford, 2003.

TORRES, Haroldo G. et al. Pobreza e espaço: padrões de segregação em São Paulo. Estudos Avançados, São Paulo, v. 17, n. 47, 2003.

VAN ZANTEN, Agnés. L École de la periferia (a escola da periferia revisitada). In: Kawczyk, Nora (Org.). Sociologia do ensino médio. Crítica do economicismo na política educacional. São Paulo: Cortez, 2005. (Xerox).

VIGNOLI, J. R. Movilidad cotidiana, desigualdade social y segregacion residencial em cuatro metropolis de America Latina. EURE, Santiago, v. 4, n. 103, 2008.

VILLAÇA, Flávio. Espaço intra urbano no Brasil. São Paulo: Studio Nobel, 1998.

WACQUANT, Loic. As Duas Faces do Gueto. São Paulo: Boitempo, 2008.

WILSON, William J. The Truly Disavantaged. The Inner City, the underclass and Public Policy. Chicago: The University of Chicago Press, 1987. 


\section{Dados da autora}

Inaiá Maria Moreira de Carvalho

Doutora em Sociologia, Professora do Programa de Políticas Sociais e Cidadania da Universidade Católica do Salvador. Pesquisadora Senior do Centro de Pesquisas da Universidade Federal da Bahia e do Observatório das Metrópoles, Núcleo de Salvador. Bolsista de Produtividade em pesquisa do Cnpq. E-mail: inaiammc@ufba.br LATTES iD LATTES iD http://lattes.cnpq.br/6436834586482218. 